НАУКОВИЙ ВІСНИК

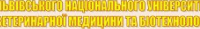

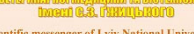

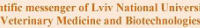

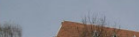
IM 1. Том 22 № 94 2020

\section{Науковий вісник Яьвівського національного університету} ветеринарної медицини та біотехнодогій імені С.3. Гжицького. Серія: Харчові технологіі

\section{Scientific Messenger of Lviv National University} of Veterinary Medicine and Biotechnologies.

Series: Food Technologies

ISSN 2519-268X print

ISSN $2707-5885$ online doi: 10.32718/nvlvet-f9410

https://nvlvet.com.ua/index.php/food

UDC 664.653.4

\title{
Application of biotechnological method of fat reduction in fish snack technology
}

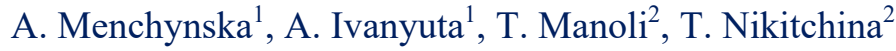 \\ ${ }^{1}$ National University of Life and Environmental Sciences of Ukraine, Kyiv, Ukraine \\ ${ }^{2}$ Odessa National Academy of Food Technologies, Odessa, Ukraine
}

Article info

Received 07.09.2020

Received in revised form 08.10 .2020

Accepted 09.10.2020

National University of Life and Environmental Sciences of Ukraine, Heroes of Defense Str., 11, Kyiv, 03041, Ukraine.

Tel: $+38-097-658-38-88$

+38-096-879-07-22

E-mail: menchynska@ukr.net, nastasushka@bigmir.net

Odesa National Academy of Food Technologies, Kanatna Str., 112, Odessa, 65039, Ukraine.

Tel.: +38-068-253-09-76.

E-mail:manoli.tatiana68@gmail.com nikitchinati@ukr.net
Menchynska, A., Ivanyuta, A., Manoli, T., \& Nikitchina, T. (2020). Application of biotechnological method of fat reduction in fish snack technology. Scientific Messenger of Lviv National University of Veterinary Medicine and Biotechnologies. Series: Food Technologies, 22(94), 50-54. doi: $10.32718 /$ nvlvet-f9410

The article deals with the research aimed at developing an enzymatic method for removing the subcutaneous fat in the technology of fish snacks production. Currently, fish snacks are popular among consumers. However, due to fierce market competition, the priority is to develop new raw materials, improve the taste characteristics of snacks and increase the shelf life of finished products. The most common commercial fish species of Ukraine caught in sufficient quantities are Black Sea sprat (Sprattus sprattus) and European anchovy (Engraulis encrasicolus). The main problem in the production of quality snack products is the high fat content in these raw materials. Oxidation of the subcutaneous layer of fat leads to an unpleasant odor and taste, and as a result - reduction of the shelf life of the product. One possible way to solve these problems is to remove lipids using biotechnology. Experiments how to solve the problem of removing the subcutaneous fat using a biotechnological method of processing are described in this work. The process of the subcutaneous fat removing has been performed using a complex of plant lipolytic enzymes extracted from wheat bran. The change in the mass fraction of fat in fish raw materials depending on the duration of the fermentation process under the action of wheat bran lipase has been studied. Results of the research showed, that the mass fraction of Black Sea sprat fat under the action of a complex of wheat bran enzymes had decreased from 12 to $4.5 \%$. The optimal temperature of the complex of lipolytic enzymes of wheat bran has been determined. The hydrolysis of fat is almost nonexistent at the temperature range from 0 up to $5{ }^{\circ} \mathrm{C}$. The greatest activity of enzymes is observed at a temperature of $25 \ldots 35^{\circ} \mathrm{C}$ and within 30 min of hydrolysis $7 \ldots 8 \%$ of fat is being removed. The optimal $\mathrm{pH}$ value for enzymatic degreasing has been investigated. It has been found that the fastest breakdown of fat occurs at $p H$ values from 7 to 8 and is $7 \ldots 8 \%$ of fat in 30 minutes. Based on the research results, a technological scheme for the production of fish snacks has been developed.

Key words: dried fish products, Black Sea sprat, fat breakdown, lipolytic enzymes, wheat bran.

\section{Застосування біотехнологічного способу видалення жиру в технології рибних снеків}

\author{
А. Менчинська ${ }^{1}$, А. Іванюта ${ }^{1}$, T. Манолі ${ }^{2}$, Т. Нікітчіна ${ }^{2}$ \\ ${ }^{1}$ Національний університет біоресурсів і природокористування Украӥни, м. Київ, Украӥна \\ ${ }^{2}$ Одеська національна академія харчових технологій, м. Одеса, Украӥна
}

Робота містить дослідження, спрямовані на розроблення ферментативного способу видалення підшкірного шару жиру в технології виготовлення рибних снеків. На даний час рибні снеки користуються популярністю серед споживачів. Але в умовах жсрсткої ринкової конкуренції пріоритетним напрямком діяльності є освоєння нових сировинних об'єктів, поліпшення смакових характеристик снеків та збільшення терміну зберігання готової продукції. Найпоширенішими промисловими видами риб Украӥни, щзо виловлюються в достатній кількості, є азово-чорноморська кілька (Sprattus sprattus) ma хамса (Engraulis encrasicolus). Основною проблемою при виробництві якісної снекової продукиії з иієї сировини є високий вміст жиру. Окиснення підикірного ширу жиру призводить до появи неприємного запаху і смаку, тобто до зменшення терміну придатності продукту. Одним із можливих иляхів 
вирішення цих проблеми є видалення ліпідів біотехнологічним иляхом. Спроби вирішення питання видалення підшкірного шиару жиру за допомогою біотехнологічного способу обробки викладені в даній роботі. Процес видалення підщкірного шару жиру проводили за допомогою комплексу рослинних ліполітичних ферментів, екстрагованих з пшеничних висівок. В роботі досліджено зміну масової частки жиру в рибній сировині залежно від тривалості процесу ферментації під дією ліпази пшеничних висівок. В результаті досліджень встановлено, що масова частка жиру шпроту чорноморського під дією комплексу ферментів пшеничних висівок зменшується з 12 до 4,5\%. Визначено оптимальну температуру дї комплексу ліполітичних ферментів пиеничних висівок. В діапазоні температур від 0 до $5{ }^{\circ} \mathrm{C}$ за гідроліз жиру майже не відбувається. Найбільша активність ферментів спостерігається за температури $25 \ldots 35^{\circ} \mathrm{C}$ і протягом 30 хв гідролізу видаляється $7 \ldots 8 \%$ жиру. Досліджено оптимальне значення рН при ферментативному знежиренні. Встановлено, щз найшвидше розщеплення жиру протікає при значеннях рН від 7 до 8 і становить $7 . . .8 \%$ жиру за 30 хвилин. На основі результатів досліджень розроблено технологічну схему виготовлення рибних снеків

Ключові слова: сущені рибні продукти, чорноморська кілька, розщеплення жиру, ліполітичні ферменти, пшеничні висівки.

\section{ВстуII}

На сьогодні снекові продукти користуються популярністю серед споживачів у всьому світі. Сучасний темп життя зумовлює необхідність швидкого і зручного варіанту для перекусу. Разом з тим в останні роки люди все частіше віддають перевагу натуральним продуктам для здорового харчування (Strashynska \& Nikolaenko, 2017). Тому пріоритетним напрямком діяльності $є$ не лише поліпшення смакових характеристик, а й виготовлення якісних снекових продуктів підвищеної харчової та біологічної цінності.

Рибні снеки мають високу харчову цінність і представлені в широкому асортименті. Солено-сушену продукцію виготовляють 3 таких видів риб, як анчоус, камбала, минтай, хек, бички, тунець, ставридові, окуневі, тріскові та інші. Але в умовах жорсткої конкуренції на ринку снекової продукції актуальним $є$ освоєння нових сировинних об'єктів та збільшення терміну зберігання готової продукції (Jaroshevich \& Paholjuk, 2020).

Найпоширеніші промислові види риб України, що виловлюються в достатній кількості, а також в безпосередній близькості від виробничих потужностей українських виробників є дрібні азово-чорноморські риби кілька (Sprattus sprattus) та хамса (Engraulis encrasicolus). Проте ці види риб належать до сировини 3 середнім вмістом жиру (8-10\%), що суттєво ускладнює технологію їх переробки і потребує вирішення ряду технологічних проблем.

Ліпіди гідробіонтів характеризуються високим вмістом ненасичених жирних кислот, які швидко взаємодіють 3 киснем повітря i окиснюються (Rzhavskaja, 1976). Окиснення жиру призводить до пожовтіння поверхні, появи неприємного запаху i смаку, зменшення терміну зберігання продукту (Lubis, \& Buckle, 1990; Sahidi, \& Zhong 2010; Tyshchenko et al., 2019). Вторинні продукти окиснення ліпідів токсичні для організму людини і можуть викликати різні захворювання (Makarenko et al., 2018). Тому основною проблемою, що стоїть на перепоні виготовлення якісної продукції з гідробіонтів 3 високим та середнім вмістом жиру, в тому числі й снекової, є окиснення ліпідів (Chaijan et al., 2006; Cyprian et al., 2017). Одним із можливих шляхів іiі вирішення $\epsilon$ розщеплення ліпідів біологічно активними сполуками - ферментами.

Ферментативний спосіб руйнування жировмісних тканин знайшов застосування в технологіях, що передбачають виведення жиру з відходів від розбирання риби для подальшого виготовлення кормового рибного борошна. Основною технологічною операцією, що забезпечує високий вихід жиру, є гідроліз жировмісної сировини водних біоресурсів за допомогою протеолітичних ферментних препаратів мікробного, тваринного та рослинного походження. В результаті ферментативного гідролізу в сировині руйнуються білково-ліпідні комплекси, що сприяє найбільш повному виділенню ліпідів і знежиренню сировини. Відомо, що особливо інтенсивно гідроліз ліпідів проходить під дією ліпаз, тому для видалення жиру доцільно застосовувати ліполітичні ферменти (Mbatia et al., 2010; Boeva et al., 2015).

Експериментально підтверджена ефективність застосування ліпаз рослинного походження для знежирення рибного фаршу (Bezusov et al, 2016). Актуальним $€$ застосування біотехнологічного способу видалення підшкірного шару жиру з метою виготовлення якісної солено-сушеної рибної продукції тривалого терміну зберігання.

Метою роботи є застосування рослинних ліполітичних ферментів, екстрагованих 3 пшеничних висівок для видалення жиру у технології рибних снеків.

Для досягнення поставленої мети необхідно вирішити такі завдання:

- $\quad$ науково обгрунтувати необхідність та доцільність застосування біотехнологічного способу видалення жиру в технології рибних снеків;

визначити оптимальні параметри процесу гідролізу жиру під впливом ліполітичних ферментів пшеничних висівок;

обгрунтувати особливості технології рибних снеків із застосуванням біотехнологічного способу видалення жиру;

дослідити органолептичні показники якості готової продукції.

\section{Матеріал і методи досліджень}

Як рибну сировину використовували чорноморську кільку (Sprattus sprattus). Гідроліз ліпідів здійснювали за допомогою комплексу ліполітичних ферментів, екстрагованих 3 пшеничних висівок (ТУ У 46.22.014-95) - побічного продукту борошномельного виробництва, що являють собою тверду оболонку зерна, яку отримують при подрібненні зерна та сортуванні його часток за розміром і масою.

Попередньо висушені за температури $35^{\circ} \mathrm{C}$ до постійної маси пшеничні висівки подрібнювали в ступці до порошкоподібного стану. Далі висівки заливали 
водою (ГМ 1:4) температурою $35^{\circ} \mathrm{C}$ та витримували 30 хв, перемішуючи. Після чого відфільтрували через фільтрувальний папір. Отриманим екстрактом заливали розібрану на пласт без голови та хребтової кістки рибу і витримували $30 \ldots 45$ хв за різних температур i значень рН. При дослідженні впливу вакууму на видалення жиру процес ферментації проводили в ексикаторі, з'єднаному з вакуумним насосом, створювали розрідження 0,8 кгс/ $\mathrm{cm}^{2}$ за температури $25{ }^{\circ} \mathrm{C}$.

Після процесу ферментації рибу споліскували водою, витримували для стікання зайвої вологи і визначали зміну масової частки жиру за методом Сокслета, згідно з ГОСТ 7636-85. Отримані результати порівнювали 3 контрольним зразком - масовою часткою жиру риби, не обробленої ферментним препаратом, визначеною раніше.

\section{Результати та їх обговорення}

Найважливішою складовою ефективного перебігу біотехнологічних процесів $є$ забезпечення оптимальних умов для функціонування ферментів. Основними факторами, що впливають на процес ферментації, $\epsilon$ тривалість, температура та $\mathrm{pH}$ середовища.

На першому етапі досліджень визначали зміну масової частки жиру під дією ліпази пшеничних висівок впродовж 60 хв (рис. 1).

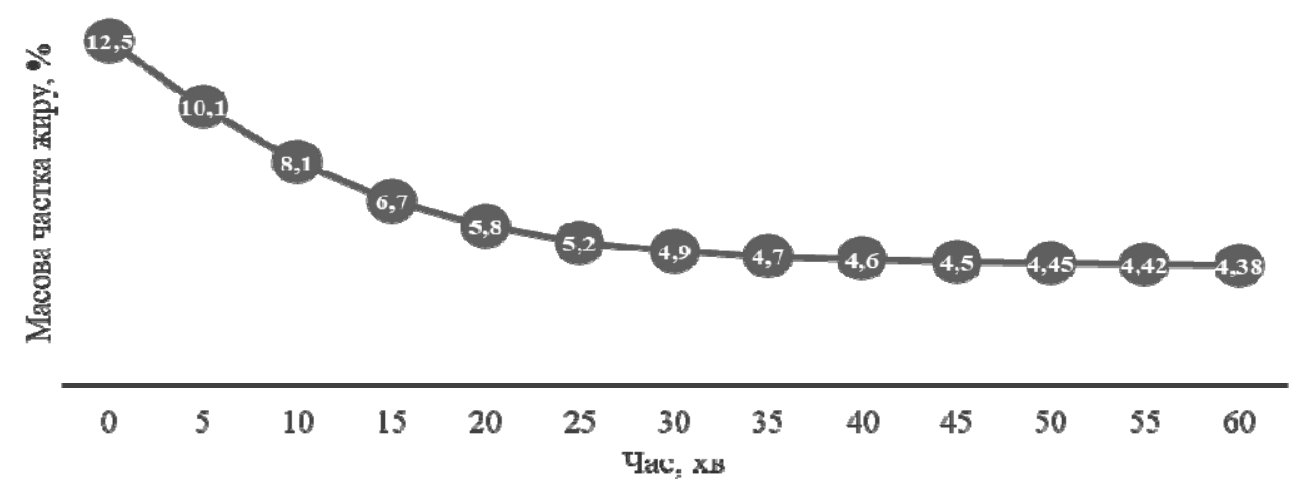

Рис. 1. Залежність впливу тривалості ферментації на зміну масової частки жиру кільки чорноморської

Результати досліджень показали, що масова частка жиру експериментального зразка під дією комплексу ферментів пшеничних висівок протягом 45 хв зменшується $з 12,5$ до 4,5 \%, тобто майже в три рази. Одержані результати підтверджують доцільність застосування біотехнологічних методів, заснованих на використанні комплексу ферментів рослинної сировини для видалення $7 \ldots 8$ \% жиру з рибної сировини.
Швидкість ферментативного каталізу залежить від температури середовища. Для визначення температурного оптимуму дії комплексу ліполітичних ферментів пшеничних висівок ферментацію риби проводили за різних температур за однаковий для всіх зразків час $30 . .45$ хв (рис. 2).

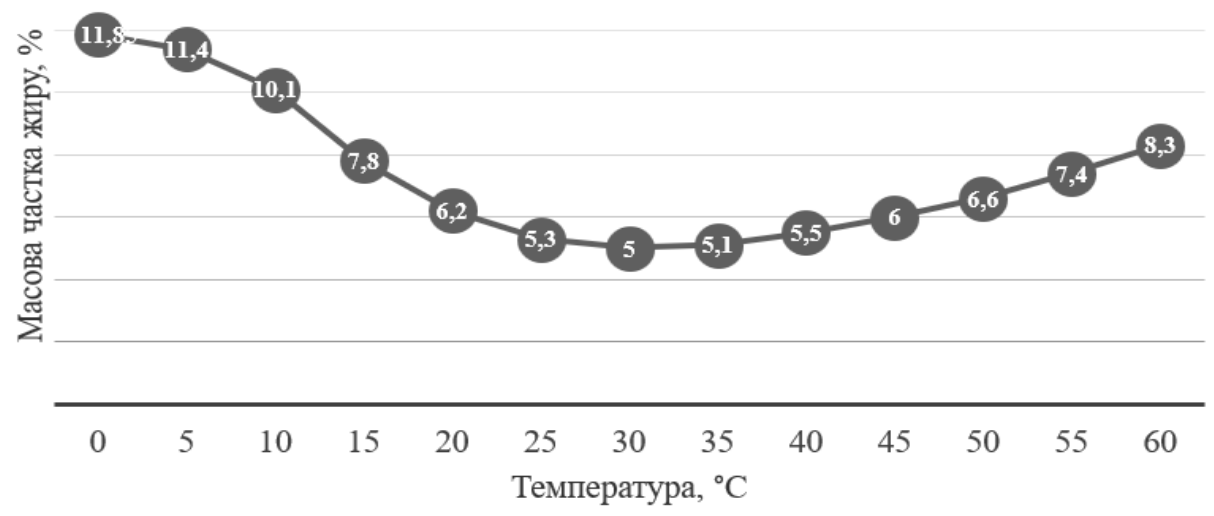

Рис. 2. Вплив температури середовища на зміну масової частки жиру кільки чорноморської

Результати досліджень показали, що ліпаза пшеничних висівок діє в достатньо широкому діапазоні температур - від 20 до $45^{\circ} \mathrm{C}$. В діапазоні температур від 0 до $5^{\circ} \mathrm{C}$ за означений проміжок часу гідроліз жиру майже не відбувався. В діапазоні від 5 до $20^{\circ} \mathrm{C}$ швидкість гідролізу зростає i за 30 хв. видаляється $1 \ldots 6 \%$ жиру, але найбільша активність спостерігається при $25 \ldots 35^{\circ} \mathrm{C}$ і за 30 хв видаляється $7 \ldots 8 \%$ жиру. В діапазоні температур від 45 до $60 \mathrm{C}$ швидкість гідролізу знижується і за 30 хв видаляється $4 . .6 \%$ жиру.

Для визначення оптимального значення $\mathrm{pH}$ для комплексу ліполітичних ферментів пшеничних висівок ферментацію риби проводили при різних значеннях рН за однаковий для всіх зразків час $-30 \ldots 45$ хв (рис. 3). 


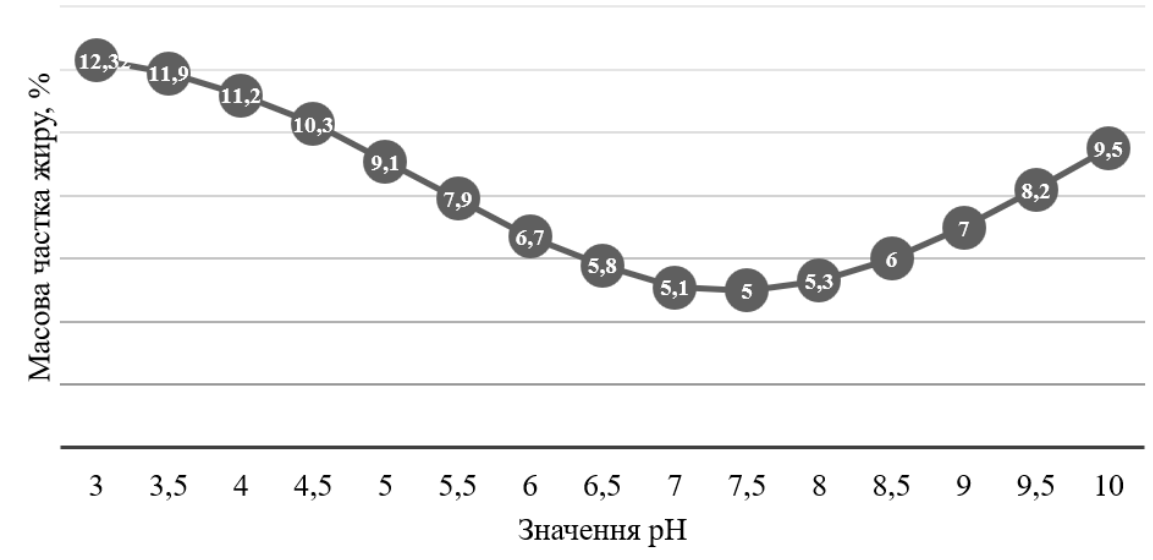

Рис. 3. Вплив рН на зміну масової частки жиру кільки чорноморської

За отриманими даними робимо висновок, що в діапазоні $\mathrm{pH}$ від 3 до 4 масова частка жиру майже не змінюється. В діапазоні від 5 до 6 швидкість гідролізу ліпідів зростає і становить $3 \ldots .5 \%$ жиру за 30 хв, але найшвидше розщеплення жиру протікає при значеннях $\mathrm{pH}$ від 7 до 8 і становить $7 \ldots 8 \%$ жиру за 30 хв. В діапазоні від 9 до 10 швидкість гідролізу починає знижуватися і становить $3 \ldots 5 \%$ жиру за 30 хв.

В результаті дослідження впливу ферментації під вакуумом на зміну масової частки жиру кільки чор- номорської встановлено, що зменшення кількості ліпідів порівняно з обробкою при атмосферному тиску є незначним і залишилося на рівні $4,5 \ldots 6 \%$. Але при цьому зменшився час ферментації - вказаних результатів вдалося досягти за $20 \ldots 30$ хвилин проти $30 . .45$ хвилин при атомсферному тиску (рис. 4).

На підставі експериментальних досліджень розроблено технологічну схему виробництва рибних снеків з використанням біотехнологічного способу видалення підшкірного шару жиру (рис. 5).

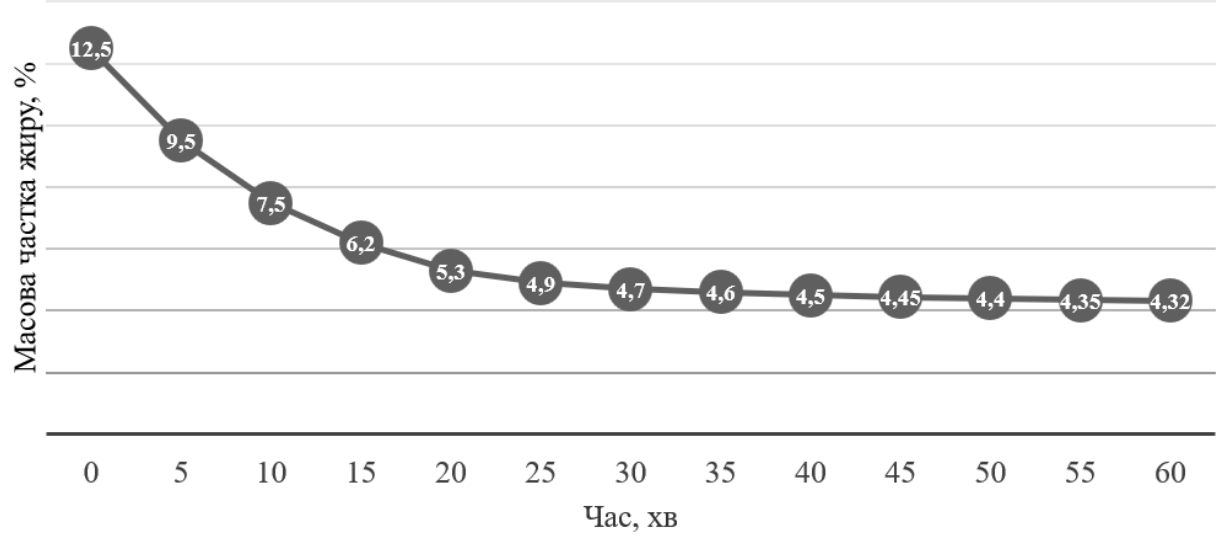

Рис. 4. Залежність впливу ферментації під вакуумом на зміну масової частки жиру кільки чорноморської від часу

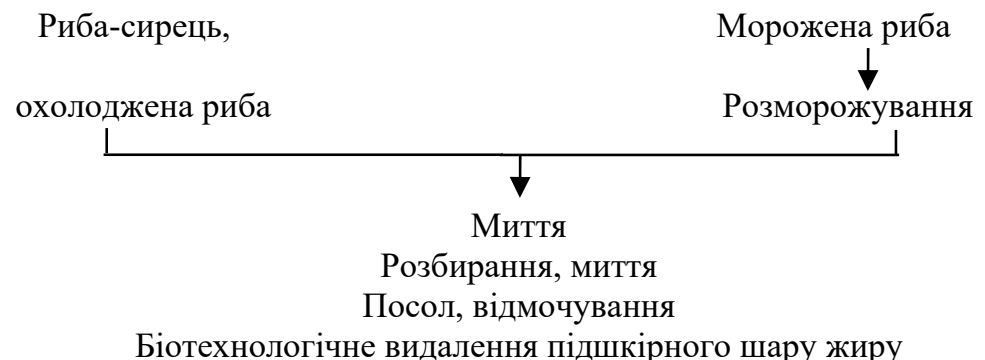

Біотехнологічне видалення підшкірного шару жиру

Сушіння

Охолодження

Упакування

Маркування

Зберігання

Рис. 5. Технологічна схема виробництва снеків з використанням біотехнологічного способу видалення підшкірного шару жиру 
3 метою дослідження впливу попередньої ферментативної обробки риби на органолептичні показники рибних снеків після завершення процесу сушіння робили порівнювальну органолептичну оцінку риби 3 попереднім ферментативним видаленням підшкірного шару жиру і риби без попередньої обробки. Результати досліджень наведені в таблиці 1.

\section{Таблиця 1}

Порівняльна органолептична оцінка рибних снеків

\begin{tabular}{lcc}
\hline \multicolumn{1}{c}{ Показник оцінки } & Риба без попередньої & Риба з попереднім ферментативним \\
ферментативної обробки & видаленням жиру \\
\hline Колір поверхні & Світло-сірий & Світло-сірий \\
Пожовтіння & Незначне & Відсутнє \\
Вологість & Суха & Суха \\
Запах & Незначний запах окисненого жиру & Без запаху окисненого жиру \\
Смак & Своєрідний & Своєрідний \\
Твердість & Тверда & Тверда \\
Шаруватість & Волокниста & Волокниста \\
Маслянистість & Значно масляниста & Незначно масляниста \\
\hline
\end{tabular}

За отриманими даними можна зробити висновок, що у попередньо обробленої ферментним препаратом риби в процесі сушіння спостерігалося значно менше виділення жиру на поверхню, ніж у риби без ферментативної обробки, що покращує зовнішній вигляд та гарантує триваліший час зберігання.

\section{Висновки}

На основі результатів досліджень встановлено, що обробка розібраної риби комплексом ліполітичних ферментів 3 пшеничних висівок дозволяє знизити масову частку підшкірного шару жиру кільки чорноморської майже втричі, це свідчить про доцільність застосування біотехнологічного способу видалення жиру в технології рибних снеків. Визначено раціональні параметри процесу гідролізу: тривалість $30 \ldots 45$ хв за температури $35 \ldots 40{ }^{\circ} \mathrm{C}$ та $\mathrm{pH} 7 . .8$. Розроблено технологічну схему виробництва снеків з використанням біотехнологічного способу видалення підшкірного шару жиру. Порівняльна органолептична оцінка снеків з риби, попередньо обробленої ферментним препаратом, та з риби без попередньої обробки підтверджує доцільність застосування біотехнологічного способу видалення жиру в технології сушених рибних продуктів.

\section{References}

Bezusov, A., Manoli, T., Nikitchina, T., Glushkov, O., \& Barysheva, Ja. (2016) Biotehnologicheskie metody v proizvodstve farsha iz melkih azovo-chernomorskih ryb. Visnik Nac. tehn. un-tu "HPI", 42(1214), 173-178. doi: 10.20998/2413-4295.2016.42.28 (in Ukrainian).

Boeva, N. P., Petrova, M. S., Artjomova, A. G., \& Baskakova, Ju. A. (2015). Novye podhody $\mathrm{k}$ tehnologii pishhevogo rybnogo zhira iz golov lososevyh ryb roda Oncorhynchus. Trudy VNIRO, 158, 162-166. (in Russian).

Chaijan, M., Benjakul, S., Visessanguan, W., \& Faustman, C. (2006). Changes of lipids in sardine (Sardinella gibbosa) muscle during iced storage. Food Chemistry, 99(1), 83-91. doi: 10.1016/j.foodchem.2005.07.022.
Cyprian, O, Sveinsdottir, K., Nguyen V. M., Tomasson, T, Thorkelsson, G., \& Arason, S. (2017) Influence of lipid content and packaging methods on the quality of dried capelin (Mallotus villosus) during storage. J Food Sci Technol, 54(2), 293-302. doi: 10.1007/s13197-016-2462-y.

Jaroshevich, T., \& Paholjuk, O. (2020). Ukrai'ns'kyj rynok ryby ta moreproduktiv: problemy ta perspektyvy. Tovaroznavchyj visnyk, 1(13), 40-51. doi:10.36910/6775-2310-5283-2020-13-04 (in Ukrainian).

Lubis, Z., \& Buckle, K. A. (1990). Rancidity and lipid oxidation of dried-salted sardines. Inlernational Journal of Food Science and Technology, 25, 295303. doi: 10.1111/j.1365-2621.1990.tb01085.x.

Makarenko, M. A, Malinkin, A. D., Bessonov, V. V., Sarkisjan, V. A., \& Kochetkova, A. A. (2018). Produkty vtorichnogo okislenija pishhevyh masel i zhirov. Ocenka riskov dlja zdorov'ja cheloveka. Vopr. Pitanija, 6(87), 125-138. doi: 10.24411/0042-88332018-10074 (in Russian).

Mbatia, B., Adlercreutz, D., Adlercreutz, P., Mahadhy, A., Mulaa, F., \& Mattiasson, B. (2010). Enzymatic oil extraction and positional analysis of $\omega-3$ fatty acids in Nile perch and salmon heads. Process Biochemistry, 45(5), 815-819. doi: 10.1016/j.procbio.2010.02.010.

Rzhavskaja, F. M. (1976). Zhiry ryb i morskih mlekopitajushhih. Pishhevaja promyshlennost', Moskva (in Russian).

Sahidi, F., \& Zhong, Y. (2010). Lipid oxidation and improving the oxidative stability. Chem Soc Rev, 39, 4067-4079. doi: 10.1039/b922183m.

Strashynska, L., \& Nikolaenko, I. (2017). Marketyngovi aspekty rozvytku rynku snekiv v Ukrai'ni. Naukovi praci NUHT, 23 (1), 75-84. URL: http://nbuv.gov.ua/UJRN/Npnukht_2017_23_1_10 (in Ukrainian).

Tyshchenko, L., Shtonda, O., Pylypchuk, O, Menchynska A., \& Shakhvorostova, V. (2019). Poultry fats. Specific features of their composition and characteristics of their oxidation resistance. Food science and technology, 13(4), 69-75. doi: 10.15673/fst.v13i4.1569. 